\title{
UTJECAJ ODZIVA PLITKO TEMELJENE ARMIRANOBETONSKE OKVIRNE KONSTRUKCIJE NA LIKVEFAKCIJSKI POTENCIJAL TLA
}

\author{
Damir Džakić \\ Projekt konstrukcija F.I. d.o.o., Zagreb, mag.ing.aedif. \\ Ivan Kraus \\ Sveučilište Josipa Jurja Strossmayera u Osijeku, Građevinski fakultet Osijek, mag.ing.aedif. \\ Mensur Mulabdić \\ Sveučilište Josipa Jurja Strossmayera u Osijeku, Građevinski fakultet Osijek, prof.dr.sc.
}

\begin{abstract}
Sažetak: Nakon katastrofalnih posljedica potresa na Aljasci i u Niigati 1964. godine, Seed i Idriss su razvili i objavili metodu za procjenu otpornosti tla na likvefakciju pod nazivom „pojednostavljeni postupak“. Dugo vremena se smatralo kako prisutnost građevine smanjuje opasnost od pojave likvefakcije, no nakon nedavnih potresa (Kobe 1995. i Kocaeli 1999.) uočeno je kako se likvefakcija pojavila ispod temelja građevina, iako nije došlo do njezinog pojavljivanja na slobodnim površinama tla u okolici građevina. U ovome radu analiziran je i uspoređen likvefakcijski potencijal tla neopterećenog objektom i tla ispod građevine, za dva profila relativno mekog tla u Osijeku pri djelovanju dva potresa različitog frekventnog karaktera i magnitude. Linearno-elastične analize vremenskim zapisom provedene su koristeći računalni program SAP2000 za slučaj neopterećen objektom i za slučaj prisutnosti i utjecaja odziva plitko temeljene armiranobetonske okvirne konstrukcije. Dodatno su prikazani i osnovni dinamički odzivi same konstrukcije u interakciji s tlom, te je dana kratka usporedba s općeprihvaćenim modeliranjem apsolutno krutih oslonaca konstrukcije.
\end{abstract}

Ključne riječi: seizmički odziv, armirani beton, okviri, plitko temeljenje, likvefakcija, meko tlo

\section{INFLUENCE OF THE RESPONSE OF A SHALLOW FOUNDED REINFORCED CONCRETE FRAME STRUCTURE ON SOIL LIQUEFACTION POTENTIAL}

\begin{abstract}
Following disastrous earthquakes in Alaska and in Niigata in 1964, Seed and Idriss developed and published a method for evaluating liquefaction resistance of soils termed the "simplified procedure". For a long time it has been considered that the presence of the building reduces the risk of liquefaction, but after the recent earthquakes (Kobe 1995. and Kocaeli 1999.) it was observed that the liquefaction occurred under the foundations of buildings, although it has not been observed in the free field around buildings. This paper analyzes and compares soil liquefaction potential in the free field and beneath the building, for two relatively soft soil profiles under the influence of two strong motions with different frequency character and magnitude. A linear-elastic time history analysis was conducted using computer program SAP2000 for the free field case and case with presence and response impact of a shallow founded reinforced concrete frame structure. In addition, basic dynamic response of the structure in interaction with the soil is presented and a short comparison is made opposite to the widely accepted rigid-base structure assumption.
\end{abstract}

Key words: seismic response, reinforced concrete, frames, shallow foundation, liquefaction, soft soil 


\section{Uvod}

Likvefakcija predstavlja jedan od najvećih izazova u području geotehničkog potresnog inženjerstva, posebice nakon uočenih značajnih oštećenja konstrukcija zbog njezine pojave u urbanim područjima, pogođenim snažnim potresima. Potencijal likvefakcije ispod građevina u praksi se uglavnom procjenjuje kroz promatranje tla kao slobodnog polja, pri čemu se ignorira bilo kakav utjecaj građevine [1]. Ovakav pristup postao je ustaljen jer se vjerovalo da je konzervativan, budući da građevina svojom težinom doprinosi „otpornosti“ tla na likvefakciju, a uz to je jednostavan za opću primjenu i ne zahtijeva razmatranje svojstava građevine. Međutim, nakon katastrofalnih potresa koji su se dogodili u 20. stoljeću (npr. Kobe 1995. i Kocaeli 1999.), uočeno je kako se likvefakcija pojavila ispod temelja građevina, iako nije došlo do njezinog pojavljivanja na slobodnim površinama tla u okolici građevina. Na temelju ovoga dalo se zaključiti da je likvefakcijski potencijal tla neopterećenog objektom različit od onoga ispod građevina $i$ to uglavnom zbog varijabilnosti u stanju naprezanja kojima je tlo podvrgnuto $u$ ta dva slučaja. U ovome radu je analiziran i uspoređen likvefakcijski potencijal tla neopterećenog objektom i tla ispod građevine. Osim toga, dodatno je analizirana i općeuvriježena pretpostavka o povoljnom utjecaju modeliranja realnih konstrukcijskih sustava pri djelovanju potresa. Na temelju trenutačno prihvaćenih rješenja iz literature, uspoređen je odziv konstrukcija bez interakcije s tlom i odziv konstrukcija s uključenom interakcijom potencijalno likvefabilnog tla „oslabljenih“ karakteristika zbog djelovanja potresa.

\section{Općenito o likvefakciji}

Slike okoliša koje su za sobom ostavili potresi Good Friday (Aljaska, $M=9,2$ ) i Niigata (Japan, $M=7,4$ ) iz 1964. godine (slika 1) potaknule su znanstvenike i inženjere u području geotehnike na intenzivnije istraživanje problema likvefakcije. Likvefakcija se definira kao transformacija nekoherentnog tla iz čvrstog u tekuće (tj. likvefirano) stanje, a nastaje kao posljedica porasta pornog tlaka i smanjenja efektivnih naprezanja [2], [3]. Povećanje pornog tlaka nastaje kao posljedica cikličkih posmičnih deformacija u tlu, čije čestice se nastoje zbiti i zauzeti stabilan položaj. Ovakva promjena stanja se najčešće javlja kod slabo do umjereno zbijenih nekoherentnih tala sa spriječenim dreniranjem [2], [3].
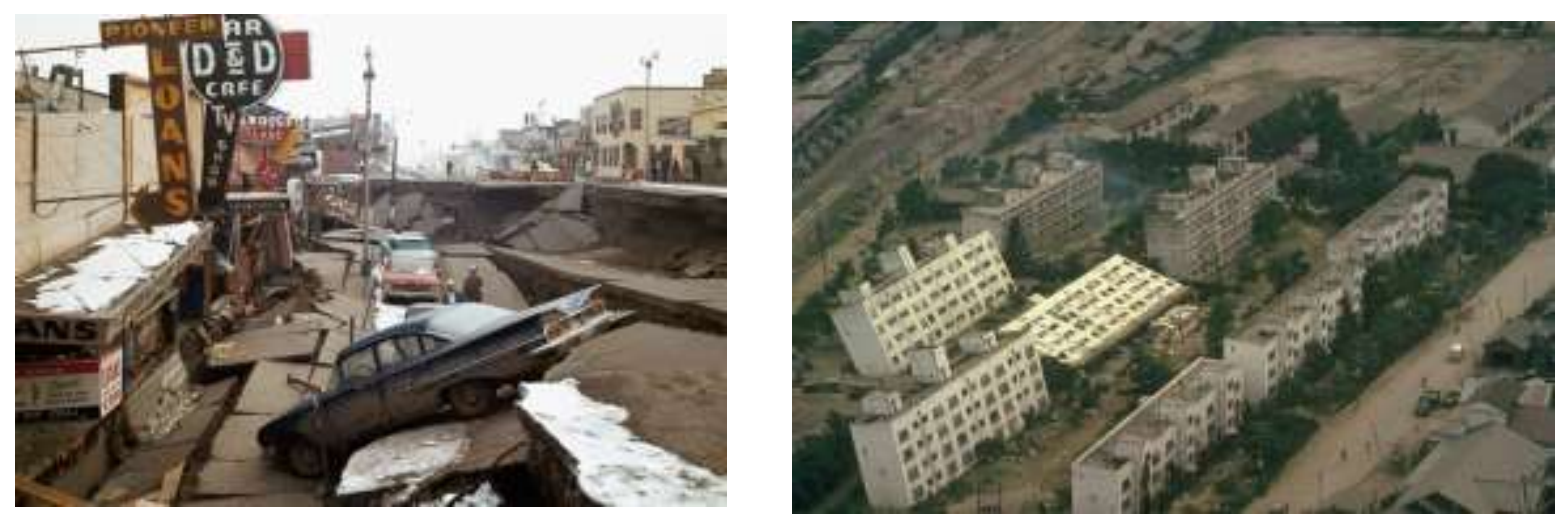

Slika 1 - Posljedice pojave likvefakcije nakon potresa iz 1964. godine: Aljaska (lijevo) [4] i Niigata (desno)

[5]

Ako postoje uvjeti slobodnog dreniranja tla, volumen tla će se smanjiti i do likvefakcije neće doći. Međutim, pri djelovanju potresa i zbog velike brzine cikličkog deformiranja, a uz spriječeno dreniranje, promjena volumena se ne može ostvariti [2]. Posljedično tome, sva djelovanja se prenose s čestica tla na pornu vodu, što rezultira povećanjem pornog tlaka (slika 2) i smanjenjem nosivosti tla.

Iz slike 2 vidljivo je kako bi u normalnim uvjetima, pri efektivnom naprezanju $\sigma_{0}^{\prime}$, došlo do dreniranja i promjene poroziteta za vrijednost $\Delta e$. No, u slučaju spriječenog dreniranja porozitet ostaje jednak $\left(e_{0}\right)$, pri čemu 
se efektivno naprezanje smanjuje na $\sigma_{f}^{\prime}$ uz prirast pornoga tlaka za $\Delta u$. $U$ slučaju dovoljno velikog broja ciklusa deformiranja, porni tlak $u$ bi se izjednačio s $\sigma_{0}^{\prime}$, zbog čega bi došlo do pojave likvefakcije [2].

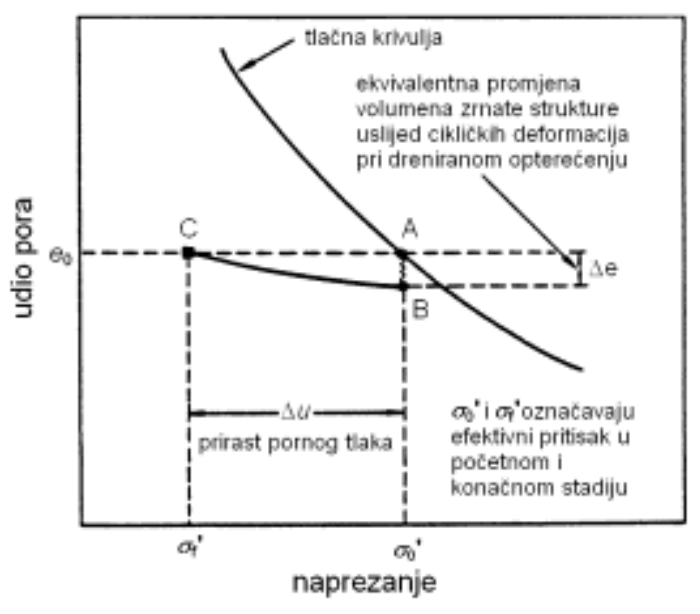

Slika 2 - Porast pornog tlaka pri cikličkom naprezanju [2] (sliku prilagodili autori)

\section{Analiza i procjena pojave likvefakcije}

Procjena potencijalne pojave likvefakcije u ovome se radu razmatra koristeći pristup preko cikličkih naprezanja, kojega su prvotno razvili Seed i Idriss 1971. godine [2]. Daljnjim razvijenim postupkom opisanim u [6], otpornost prema likvefakciji se izražava faktorom sigurnosti koji je dan izrazom:

$$
F S_{L}=\frac{C R R_{7,5}}{C S R} \cdot M S F \cdot K_{\alpha} \cdot K_{\sigma}
$$

gdje je:

$C R R_{7.5} \quad$ omjer cikličke otpornosti prema likvefakciji za potrese magnitude $M_{\mathrm{w}}=7,5$

CSR omjer cikličkih naprezanja uzrokovanih potresom

MSF faktor skaliranja magnitude potresa (slika 3)

$K_{\alpha} \quad$ faktor korekcije za statičko posmično naprezanje $T_{\text {static, }}$ ako je ono prisutno (slika 4a)

$K_{\sigma} \quad$ faktor korekcije pritiska nadsloja (ili nasipa, odnosno konstrukcije) (slika 4b).

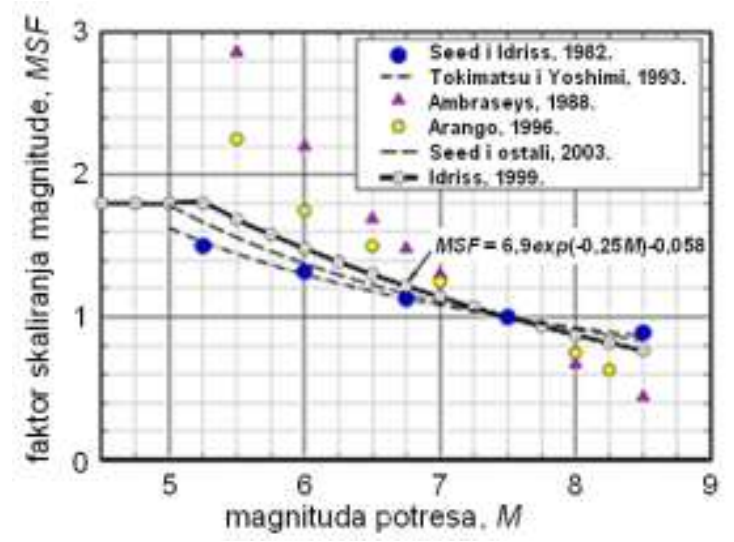

Slika 3 - Faktor skaliranja magnitude potresa MSF, ovisno o magnitudi potresa $M$ [7] (slike prilagodili autori) 


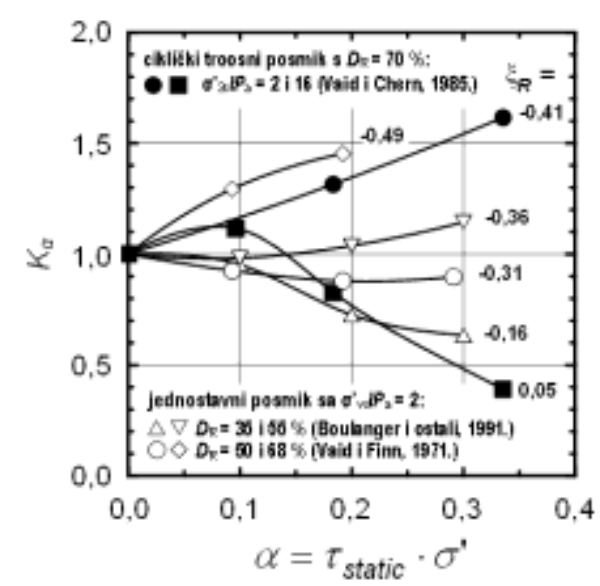

a)

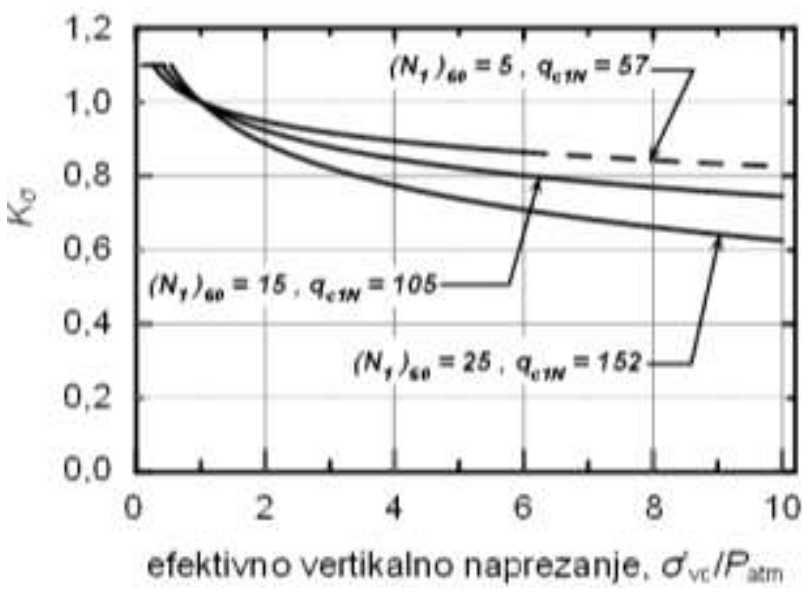

b)

Slika 4 - Faktori korekcije za proračun otpornosti prema likvefakciji [8]: a) faktor korekcije za statičko posmično naprezanje $K_{\alpha} ;$ b) faktor korekcije pritiska nadsloja $K_{\sigma}$ (slike prilagodili autori)

Budući da je postupak proračuna potencijala pojave likvefakcije za praktične primjene prilično složen, nakon niza provedenih ispitivanja je zaključeno ([2], [9]) kako se proračun može provoditi s ekvivalentnim jednolikim prosječnim posmičnim naprezanjem $\tau_{\text {av }}$ koje iznosi $65 \%$ maksimalnog posmičnog naprezanja $\tau_{\max }($ slika 5$)$.

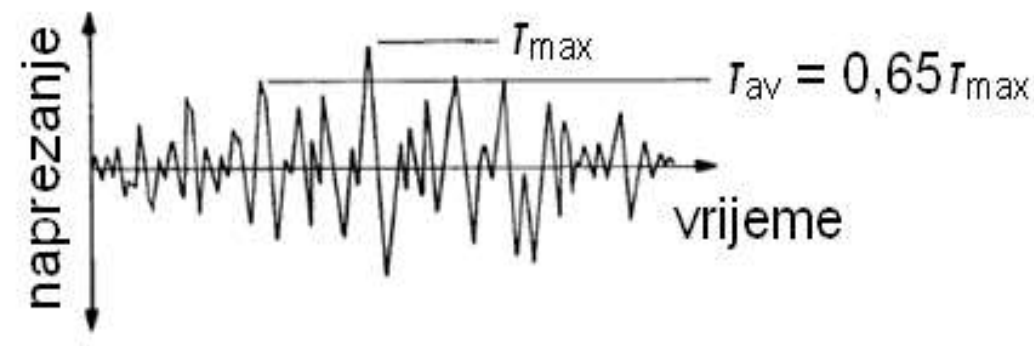

Slika 5 - Zapis seizmičkih posmičnih naprezanja u vremenu [2] (sliku uredili autori)

Uzimajući ovo u obzir, omjer cikličkih naprezanja se može odrediti sljedećim izrazom [9], [10]:

$$
C S R=0,65 \cdot \frac{\tau_{\max }}{\sigma_{0}{ }^{\prime}}=0,65 \cdot \frac{a_{\max }}{g} \cdot \frac{\sigma_{0}}{\sigma_{0}{ }^{\prime}} \cdot r_{d},
$$

gdje je:

$a_{\max } \quad$ vršno ubrzanje na površini tla

$\sigma_{0} \quad$ ukupno (totalno) vertikalno naprezanje u promatranoj točki

$\sigma_{0}^{\prime} \quad$ efektivno vertikalno naprezanje u promatranoj točki

$r_{\mathrm{d}} \quad$ faktor redukcije ovisan o dubini, kojim se uzima u obzir fleksibilnost profila tla (slika 6). 


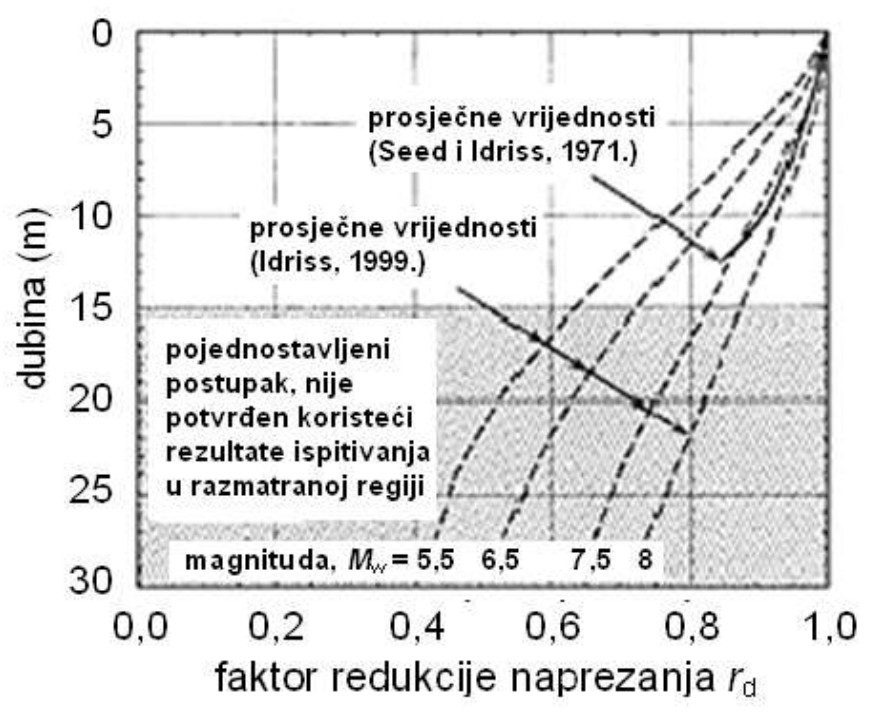

\section{Slika 6 - Dijagram ovisnost faktora redukcije naprezanja $r_{d} O$ dubini [6] (sliku uredili autori)}

Kako bi se procijenila vrijednost cikličkih naprezanja pri kojima dolazi do likvefakcije tla, provode se ciklička laboratorijska ispitivanja na reprezentativnim uzorcima. Osim toga, otpornost na likvefakciju se procjenjuje postupcima in-situ ispitivanja, npr. standardnim penetracijskim pokusom (SPT) [2], [3]. Najčešće primjenjivani postupak procjene otpornosti je upravo SPT te će se u skladu s time za određivanje omjera cikličke otpornosti CRR primijeniti izraz usvojen prema izvješću s radionice NCEER/NSF [6]:

$$
C R R_{7,5}=\frac{1}{34-\left(N_{1}\right)_{60}}+\frac{\left(N_{1}\right)_{60}}{135}+\frac{50}{\left(10 \cdot\left(N_{1}\right)_{60}+45\right)^{2}}-\frac{1}{200}
$$

gdje je $\left(N_{1}\right)_{60}$ korigirani broj udaraca u SPT pokusu (vidjeti Sliku 4b) koji se primjenjuje zbog varijabilnosti SPT sustava [2], [3], [6], a definira se kao broj udaraca pri efektivnom vertikalnom naprezanju od $100 \mathrm{kPa}$ i $60 \%$ ukupne energije udarca. Prema [6] i [9], CRR $=0,05$ označava graničnu vrijednost za koju se pri potresima s CSR $\leq 0,05$ ne očekuje pojava likvefakcije. Nadalje, prema [6] i [9], $\left(N_{1}\right)_{60}$ je ograničen na vrijednosti manje od 30 za primjenu u izrazu (3).

Cjelovita teorijska pozadina postupka procjene likvefakcije je prilično složena i opsežna te ovdje nije detaljnije izložena. Prethodno izloženi postupak je samo sažetak primijenjen pri proračunima, a cjelokupan pregled teorije može se vidjeti u npr. [2], [3] i [6].

\section{Numerički model}

\subsection{Konstrukcijski sustavi}

Linearno elastični proračuni vremenskim zapisom provedeni su na dva tropoljna ravninska armiranobetonska okvira visine četiri i osam katova. Okviri (unutarnji) su izdvojeni iz sustava konstrukcija pravilnih stambenih zgrada. Pretpostavlja se da su zgrade plitko temeljene na armiranobetonskim temeljnim pločama na mekom tlu. Geometrijske i materijalne karakteristike elemenata okvira dane su u tablici 1. Usvojena debljina stropnih i krovnih ploča jednaka je $18 \mathrm{~cm}$. Sudjelujuća širina ploča izračunata je prema preporukama danim u EC2 [11]. 


\section{Tablica 1 - Geometrijske i materijalne karakteristike konstrukcijskih elemenata}

\begin{tabular}{|c|c|c|c|c|c|c|c|}
\hline Element & $0 k v i r$ & $\begin{array}{c}L \\
{[\mathrm{~cm}]}\end{array}$ & $\begin{array}{c}\boldsymbol{b} \\
{[\mathrm{cm}]}\end{array}$ & $\begin{array}{c}\boldsymbol{h} \\
{[\mathrm{cm}]}\end{array}$ & $\begin{array}{c}\boldsymbol{b}_{\text {eff }} \\
{[\mathrm{cm}]}\end{array}$ & $\begin{array}{c}f_{\mathrm{ck}} \\
{[\mathrm{MPa}]}\end{array}$ & $\begin{array}{c}E_{\mathrm{cm}} \\
{[\mathrm{MPa}]}\end{array}$ \\
\hline Greda & $04 \mathrm{i} 08$ & 600 & 30 & 60 & 115 & 25 & 30500 \\
\hline \multirow{2}{*}{ Stup } & 04 & 300 & 40 & 40 & - & 30 & 3 \\
\cline { 2 - 8 } & 08 & 300 & 70 & 70 & - & 32000 \\
\hline
\end{tabular}

Veličine izračunatog stalnog i promjenjivog opterećenja primijenjenog na modele greda okvira dane su u tablici 2. Vlastita težina konstrukcijskih elemenata okvira je automatski uključena u programskom paketu korištenom za proračun, SAP2000 [12]. Sva opterećenja su odabrana u skladu s EC1 [13].

Tablica 2 - Opterećenje na gredama okvira

\begin{tabular}{|l|c|c|}
\hline & $\begin{array}{c}\text { Stalno opterećenje } \\
{[\mathrm{kN} / \mathrm{m}]}\end{array}$ & $\begin{array}{c}\text { Promjenjivo opterećenje } \\
{[\mathrm{kN} / \mathrm{m}]}\end{array}$ \\
\hline Grede ispod stropnih ploča & 20 & 7,50 \\
\hline Grede ispod krovnih ploča & 25 & 2,85 \\
\hline
\end{tabular}

\subsection{Temeljno tlo i potresno djelovanje}

Numerički modeli tla načinjeni su koristeći svojstva tla određena iz dvije istražne bušotine na lokaciji terminala za pretovar rasutih tereta u Luci Osijek [14]. Na temelju jednodimenzionalnog proračuna odziva tla, određeni su dinamički parametri za analizu međudjelovanja tla i konstrukcije, seizmičke pobude na površini tla za analizu međudjelovanja te likvefakcijski potencijal. Jednodimenzionalni proračun odziva tla proveden je koristeći programski paket SHAKE2000 [15], koji se zasniva na pretpostavci vertikalno rasprostirućih posmičnih valova. U bušotinama, mjereno od površine terena do dubine $30 \mathrm{~m}$, odnosno $50 \mathrm{~m}$, potvrđen je sastav tla gdje su uočeni karakteristični slojevi tla prikazani slikom 7.
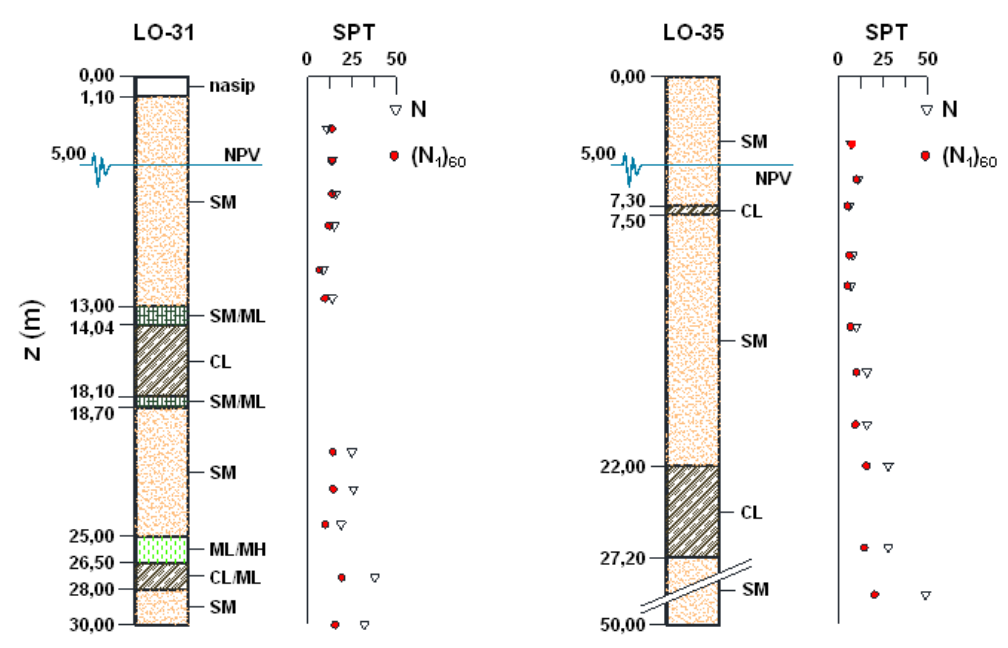

\section{Slika 7 - Raspodjela karakterističnih slojeva i rezultata mjerenja standardnim penetracijskim pokusom (SPT) po dubini profila tla razmatranih u radu [14]}

Istražnim radovima utvrđene su specifične težine tla $\gamma_{\mathrm{s}}$ koje iznose $19 \mathrm{kN} / \mathrm{m}^{3}$ za slojeve do dubine od $5 \mathrm{~m}$, te $20 \mathrm{kN} / \mathrm{m}^{3}$ za sve slojeve dublje od $5 \mathrm{~m}$. Za definiranje konačnog analitičkog profila, brzine širenja posmičnih valova $v_{s}$ određene su postupcima Down-hole i ReMi [14], a jednake su pripadnim modulima posmika pri malim 
deformacijama $G_{\max }$, prikazanima na slici 8. Prema elaboratu [14], osnovna stijena se nalazi na dubini od $100 \mathrm{~m} \mathrm{u}$ odnosu na površinu profila.

U geotehničkom elaboratu [14] su, na osnovi regionalnih seizmoloških i seizmotektonskih istraživanja, te prema relativnim utjecajima spektralnih značajki izvora potresa u regiji i atenuacijskih značajki geoloških materijala koji prenose seizmičke valove od osnovne stijene do lokacije, vjerojatnosnim pristupom određene karakteristike projektnog potresa, tj. horizontalna seizmička ubrzanja $a_{\max }$ na razini osnovne stijene: $a_{\max }=0,20 \mathrm{~g}$ za povratni period od 475 godina, što prema EC8 [16] odgovara razini No Collapse Requirement. Prema ovim podatcima definiran je elastični spektar tipa 1 za tlo kategorije A u skladu s EC8 [16].
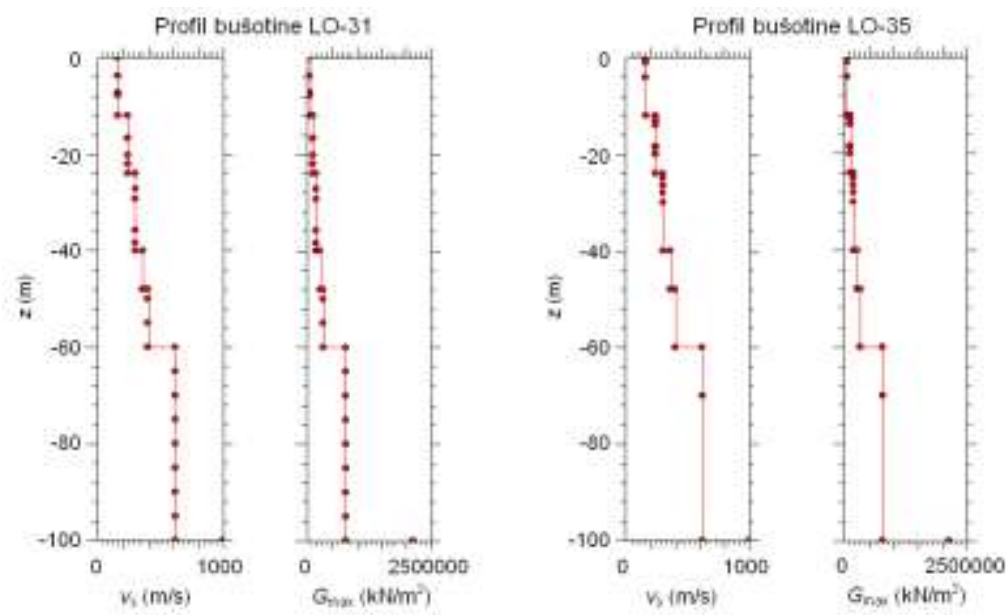

Slika 8 - Raspodjela brzine širenja posmičnih valova $v_{s}$ te modula posmika pri malim deformacijama $G_{\max }$ po dubini profila tla razmatranih radom [14]

Nadalje, postupkom koji je detaljnije opisan u [17], na temelju oblika spektra odziva definiranog u EC8 [16], odabrani su zapisi potresa Northridge 1994. i Irpinia 1980. S obzirom da su profili tla razmatrani radom definirani za lokaciju Luke Osijek koja se nalazi 4,5 km udaljena od aktivnog rasjeda Mescek-Villany-Baranja, procijenjena je maksimalna magnituda $M_{\max }$ jednaka 6,2 [14]. Zapisi su skalirani tako da odgovaraju spektru odziva tipa 1 za kategoriju tla A prema EC8 [16], uz $a_{\max }=0,20 \mathrm{~g}$. Odabrani potresi su korišteni kao pobuda na osnovnoj stijeni u jednodimenzionalnoj analizi odziva tla. Primjenom jednodimenzionalne analize izračunate su dinamičke karakteristike tla potrebne za definiranje sustava međudjelovanja tla i konstrukcije, te odgovarajući zapisi potresa na razini temeljenja konstrukcije (slika 9).
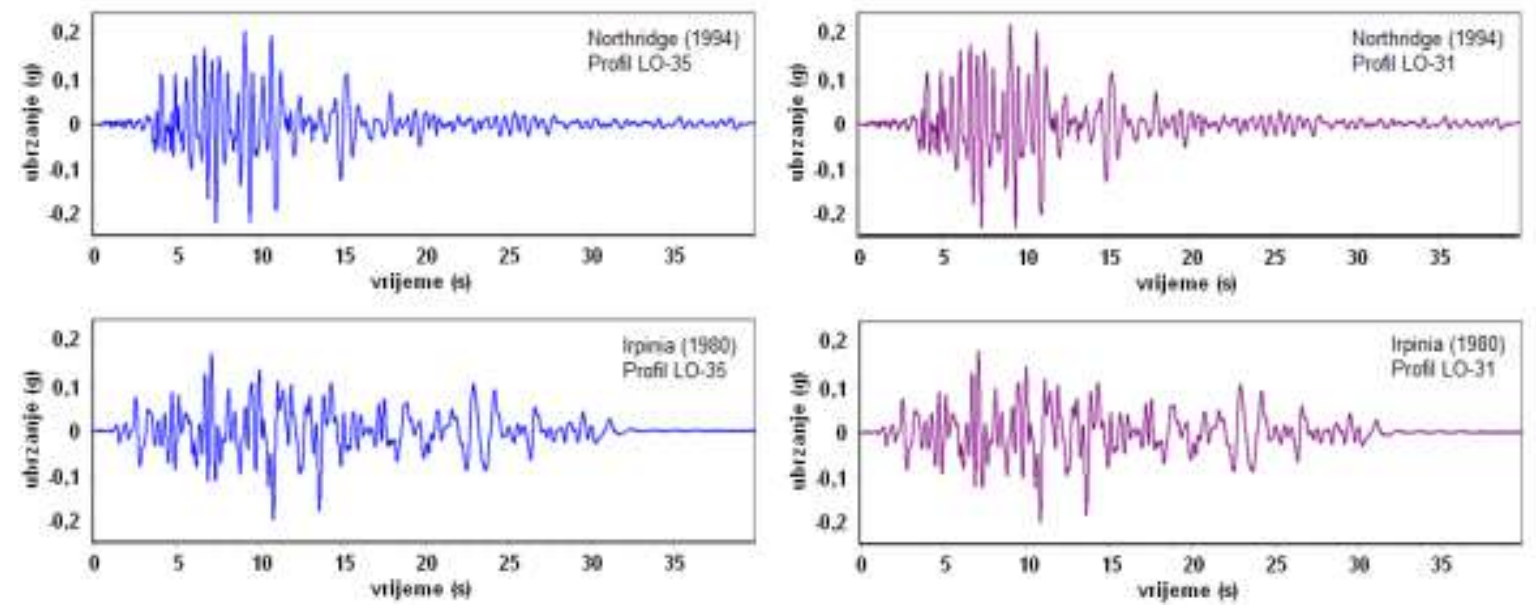

Slika 9 - Zapisi potresa na razini temeljenja konstrukcije 
Potresi na razini temeljenja korišteni su u programskom paketu SAP2000 u analizi odziva okvira. Sustav međudjelovanja tla i konstrukcije modeliran je koristeći jednostavni sustav opruga (Winklerov model) i prigušivača (eng. dash-pot).

\section{Tablica 3 - Dinamička svojstva opruga korištenih za numeričko modeliranje tla}

\begin{tabular}{|c|c|c|c|c|}
\hline \multirow{2}{*}{$\begin{array}{c}\text { Oznaka } \\
\text { profila tla }\end{array}$} & \multicolumn{2}{|c|}{ Krutost $(\mathrm{kN} / \mathrm{m})$} & \multicolumn{2}{c|}{ Prigušenje $(\mathrm{kNs} / \mathrm{m})$} \\
\cline { 2 - 5 } & horizontalna & rotacijska & horizontalno & rotacijsko \\
\hline LO-31 & 389642 & 12041308 & 6106 & 120354 \\
\hline LO-35 & 390283 & 11284564 & 6111 & 113711 \\
\hline
\end{tabular}

Dinamičke vrijednosti krutosti i prigušenja za opruge (tablica 3) su proračunate za globalni horizontalni smjer te za globalno prevrtanje za slučaj temeljenja na temeljnoj ploči kako je opisano u [18-22]. Između ostalog, tehnički izvještaj [22], koji je javno dostupan za preuzimanje, daje detaljan prikaz proračuna opruga. Pretpostavljeno je da se temeljna ploča ponaša kao kruti disk te nije modelirana, već su opruge razmještene točkasto po stupovima.

\section{Rezultati i diskusija}

Prije razmatranja rezultata likvefakcijskog potencijala tla za slučaj bez opterećenja na površini te za slučaj kada je prisutna konstrukcija, kratko su prikazani rezultati dinamičke analize tla. Za dva odabrana potresa različitog frekventnog sastava, javljaju se i bitno različiti odzivi tla, što u konačnici ima značajan utjecaj na odziv analiziranog sustava tlo - konstrukcija. Na Slici 10 može se vidjeti kako za oba potresa dolazi do značajnih amplifikacija ubrzanja.
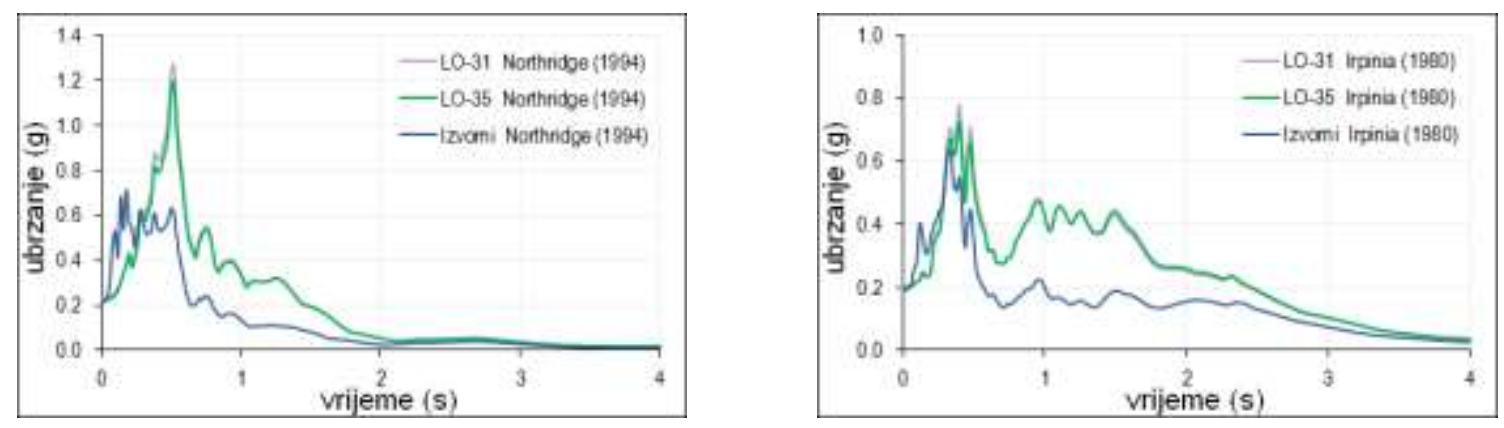

\section{Slika 10 - Spektri odziva izvornih i modificiranih potresa: Northridge 1994 (lijevo) i Irpinia 1980 (desno)}

Amplifikacija ima različit učinak na različite konstrukcije, pri čemu potres Northridge iz 1994. ima nepovoljniji utjecaj na konstrukcije s malim osnovnim periodima osciliranja (oko 0,5 s), dok potres Irpinia (1980.) nepovoljno utječe na široki spektar konstrukcije s obzirom na osnovni period osciliranja (od oko 0,5 do oko 1,5 s). Nadalje, za bolje shvaćanje učinka međudjelovanja tla i konstrukcije, tablica 4 i slika 11 redom daju prikaz osnovnih perioda osciliranja za upete okvire i okvire na oprugama, te raspodjelu ukupne poprečne sile po katu za okvire na oprugama. Očekivano, s obzirom na sliku 10 i 11, te s obzirom na rezultate dane u tablici 4, potres Northridge 1994. ima nepovoljniji utjecaj na okvir visine 4 kata budući da su osnovni periodi osciliranja okvira i potresa bliski.

Tablica 4 - Osnovni periodi osciliranja za upete okvire i okvire na oprugama

\begin{tabular}{|c|c|c|c|}
\hline \multirow{2}{*}{ Oznaka okvira } & \multicolumn{3}{|c|}{ Osnovni period osciliranja T1 za okvir: } \\
\cline { 2 - 4 } & upet u temeljno tlo & na profflu L0-31 & na profflu L0-35 \\
\hline 04 & $0,449 \mathrm{~s}$ & $0,534 \mathrm{~s}$ & $0,538 \mathrm{~s}$ \\
\hline 08 & $0,713 \mathrm{~s}$ & $0,989 \mathrm{~s}$ & $1,004 \mathrm{~s}$ \\
\hline
\end{tabular}



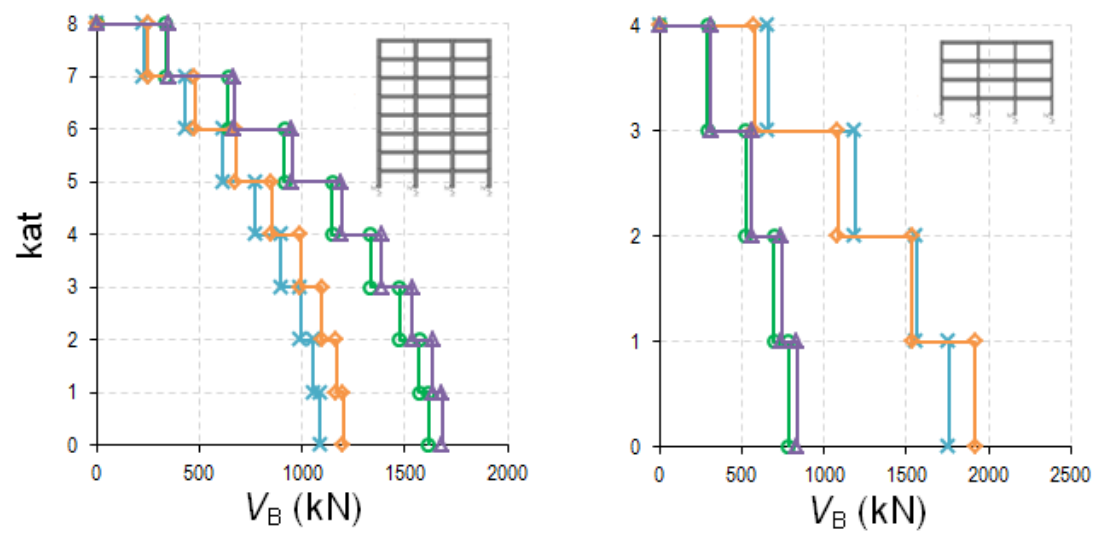

LEGENDA:

$\div$ LO-35 Northridge

$\rightarrow$ LO-35 Irpinia

$\rightarrow$ LO-31 Northridge

$\simeq$ LO-31 Irpinia

Slika 11 - Raspodjela ukupnih katnih poprečnih sila po visini za okvir s osam katova (lijevo) i okvir s četiri kata (desno)

Rezultati analize likvefakcijskog potencijala prikazani su slikama 12 i 13, iz kojih je vidljivo da se za slučaj slobodne površine likvefakcija javlja za svaku kombinaciju profila tla i potresa razmatranu ovim radom.

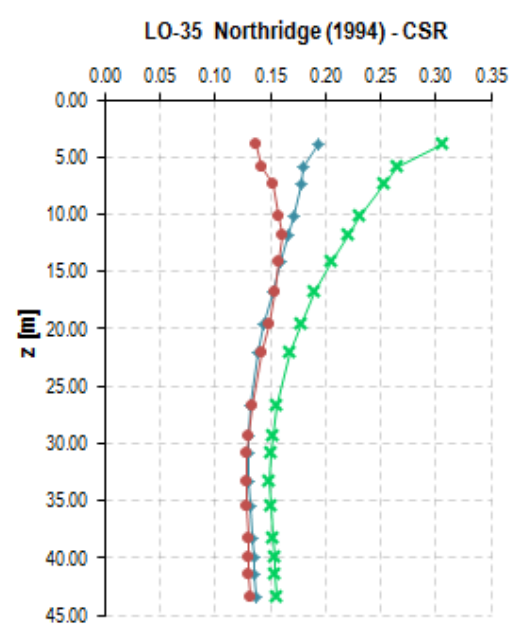

L0-35 Irpinia (1980) - CSR

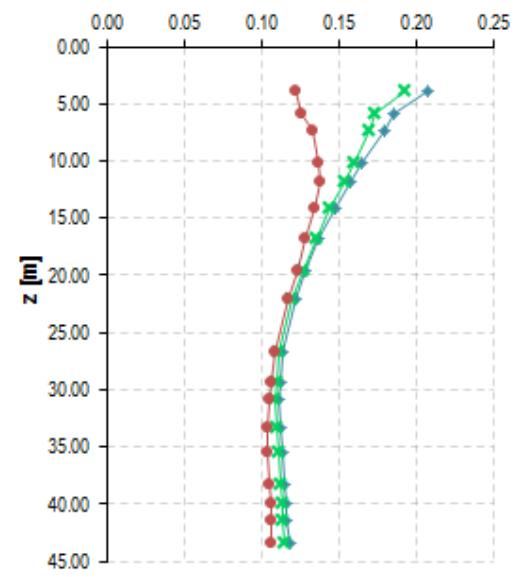

L0-35 Northridge (1994) - CRR

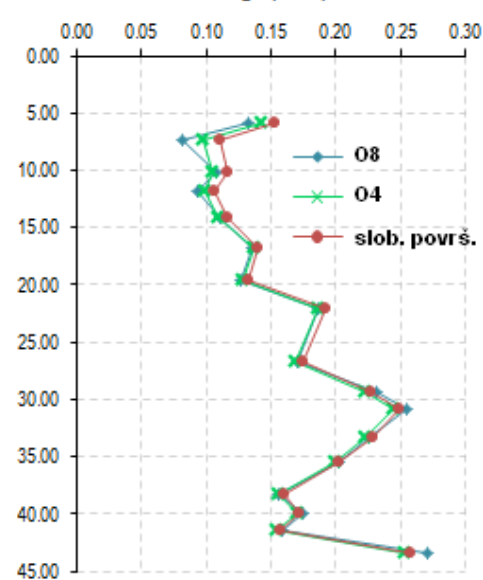

L0-35 Irpinia (1980) - CRR

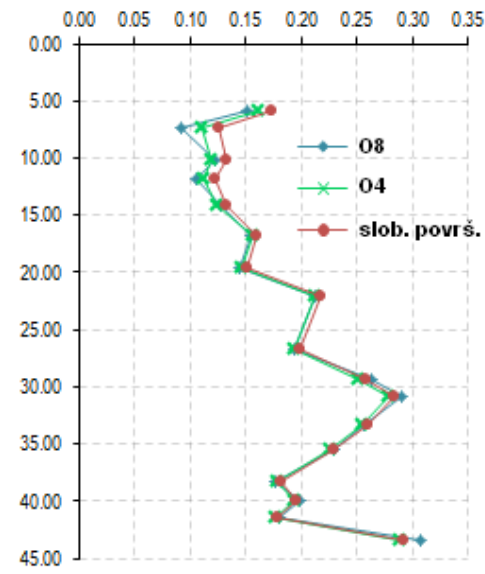

L0-35 Northridge (1994) - FSL

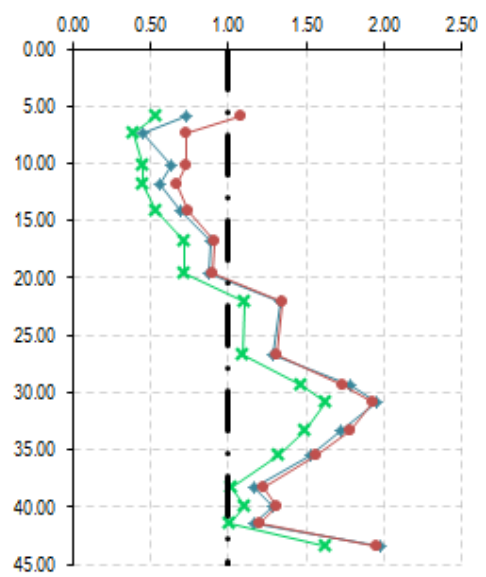

L0-35 Irpinia (1980) - FSL

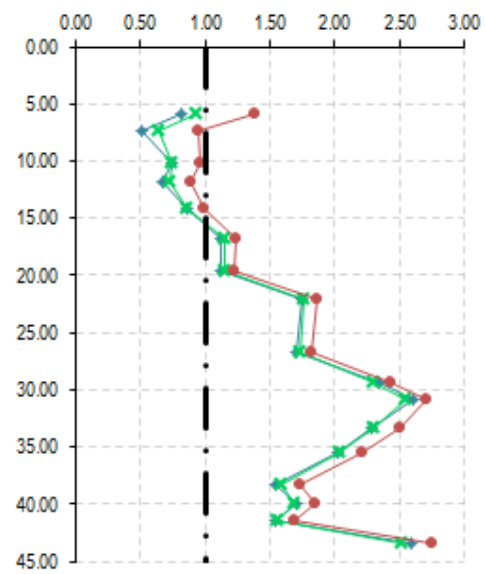

Slika 12 - Raspodjela omjera cikličkih naprezanja CSR, omjera cikličke otpornosti CRR i faktora sigurnosti od likvefakcije po dubini profila LO-35 za potres: Northridge 1994. (gore) i Irpinia 1980. (dolje) 
U slučajevima kada se na tlu nalazi konstrukcija, rezultate likvefakcijskog potencijala moguće je grupirati u parove prema prethodno spomenutim učincima amplifikacije na odziv konstrukcija. Tako se, primjerice, za slučaj potresa Northridge (velika amplifikacija pri niskim periodima osciliranja) najnepovoljniji rezultati javljaju za okvire visine 4 kata (niske, relativno krute konstrukcije) (slika 12 i 13). Osim toga, uočeno je kako je utjecaj konstrukcije na likvefakcijski potencijal izražen po cijeloj dubini profila, iako se najznačajnijim može smatrati u prvih $15-20 \mathrm{~m}$ ispod površine tla. Općenito, primijećeno je da je odziv okvira od 8 katova manje kritičan nego odziv manjeg okvira.

Zbog konzervativnosti pojednostavljenog proračuna primijenjenog u ovom radu, pretpostavlja se da do likvefakcije ipak neće doći u profilu LO-31 (slika 13) za slučajeve potresa Irpinia 1980., budući da je vrijednost faktora sigurnosti $F S L=1$ (jednadžba 1) premašena na relativno kratkom potezu, na dubini od oko $11 \mathrm{~m}$.
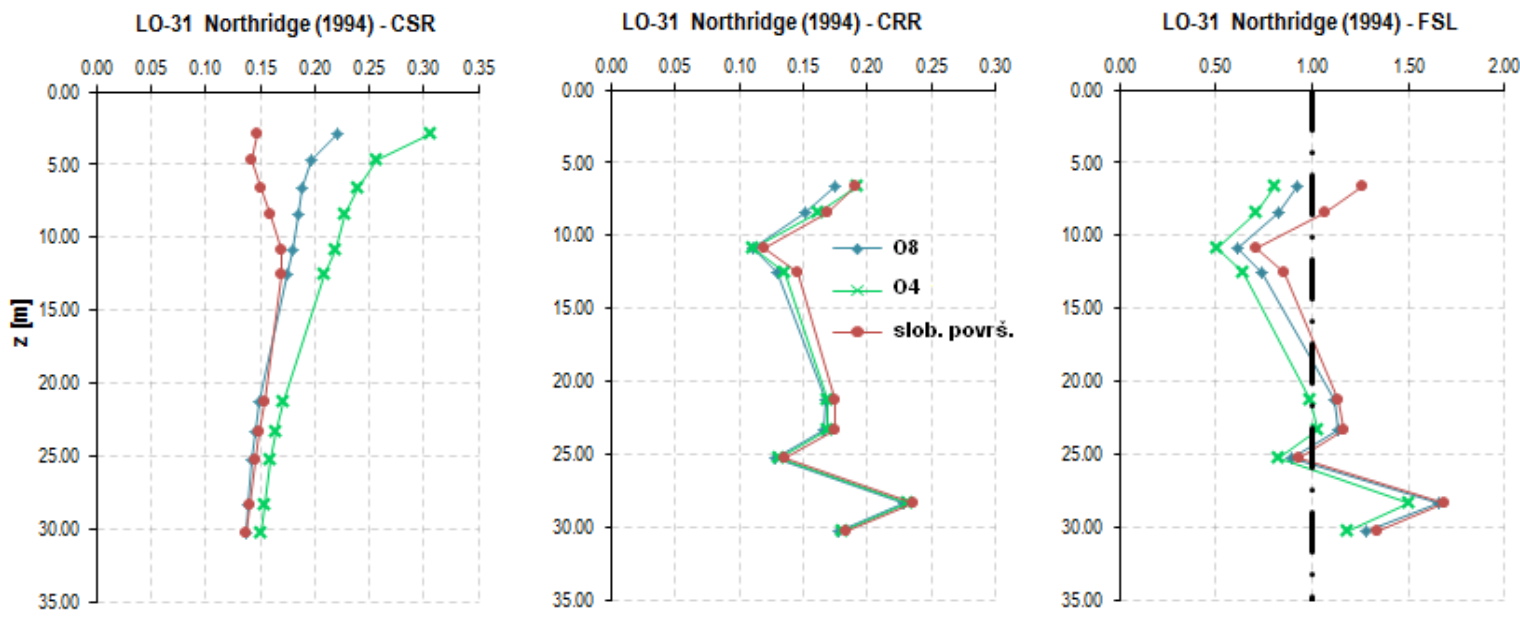

LO-31 Irpinia (1980) - CSR

LO-31 Irpinia (1980) - CRR

L0-31 Irpinia (1980) - FSL
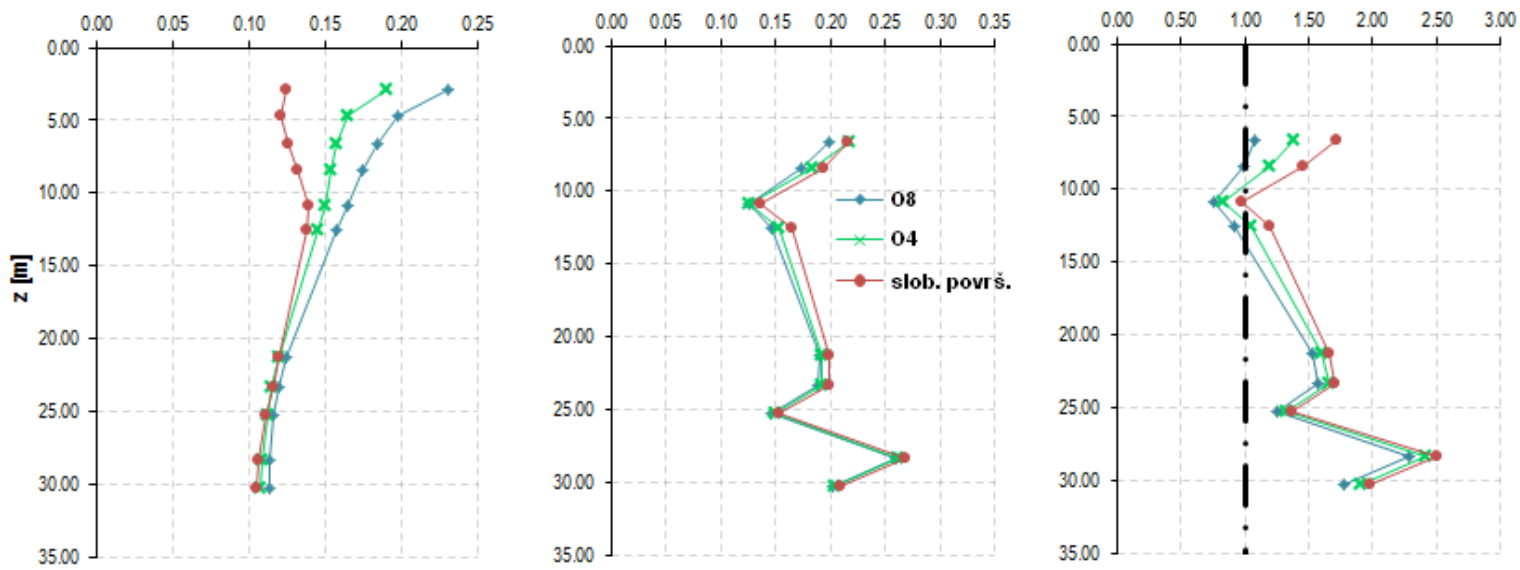

Slika 13 - Raspodjela omjera cikličkih naprezanja CSR, omjera cikličke otpornosti CRR i faktora sigurnosti od likvefakcije po dubini profila LO-31 za potres: Northridge 1994 (gore) i Irpinia 1980 (dolje)

Prisutnost konstrukcija, osim što povećava omjer cikličkih naprezanja CSR, dodatno produbljuje utjecaj likvefakcije. Značajniji utjecaj konstrukcije se u svim slučajevima u prosjeku proteže do dubine od oko $18 \mathrm{~m}$, nakon čega je omjer cikličkih naprezanja gotovo jednak onome za slobodnu površinu tla. Gledajući to u odnosu na širinu temeljenja konstrukcije, za slučajeve razmatrane u ovome radu, može se reći da dubina tla do koje seže utjecaj konstrukcije odgovara širini temelja konstrukcije. Bitno je napomenuti kako su uvjeti tla zapravo takvi da se, bez obzira na likvefakciju, građevine ne bi temeljile na ovaj način (bez znatnijeg ukopavanja ili pojačavanja tla), no ovakva situacija je analizirana upravo stoga da se pokažu mogući razlozi neadekvatnosti temeljenja te opasnosti od pojave likvefakcije zbog odziva konstrukcije. 


\section{Zaključak}

U ovome radu analizirane su pretpostavke i uspoređeni rezultati likvefakcijskog potencijala tla za slučaj bez opterećenja na površini tla i za slučaj opterećenja tla građevinom. Osim toga, dodatno je analizirana i opće uvriježena pretpostavka o modeliranju krutosti oslonaca konstrukcijskih sustava pri djelovanju potresa. Na temelju trenutačno prihvaćenih rješenja iz literature, uspoređen je odziv konstrukcija bez interakcije s tlom i odziv konstrukcija s uključenom interakcijom potencijalno likvefabilnog tla "oslabljenih" karakteristika zbog djelovanja potresa. Za potrebe proračuna korištena su dva profila mekih tala s područja Osijeka, s dovoljnom međusobnom razlikom u krutosti kako bi se naglasili različiti uvjeti tla koji se mogu pojaviti. $S$ druge strane, konstrukcijski sustavi su bitno različiti u pogledu dinamičkih karakteristika, što sveukupno daje širi spektar analiza. Pored ovoga, primijenjena su i dva bitno razlicita zapisa potresa, prvenstveno s razlikama u frekventnom sastavu, ali i u vrijednostima ubrzanja. $U$ provedenim analizama likvefakcijskog potencijala na slobodnoj površini $i$ ispod konstrukcije mogu se primijetiti velike razlike, što upućuje na znatan utjecaj konstrukcije pri pojavi ovoga fenomena. Uočeno je posebno izraženo povećanje vertikalnog naprezanja u tlu na dubini jednakoj 3,5 širine temelja. Ovakav utjecaj je prvenstveno posljedica povećanja omjera cikličkih naprezanja u tlu zbog statičkih posmičnih naprezanja od težine konstrukcije te cikličkih naprezanja zbog odziva konstrukcije. Povoljan utjecaj konstrukcije izražen je u vidu povećanja totalnih naprezanja, a time i povećanja omjera cikličke otpornosti tla, te je zato vrijednost faktora sigurnosti na likvefakciju pala pri površini, gdje se najviše osjeti utjecaj težine objekta. lako su ovi rezultati pokazali kako konstrukcija nepovoljno utječe na likvefakcijski potencijal tla, to ne mora biti nužno tako, jer je moguće da za neki drugi tip konstrukcije i drugi zapis potresa likvefakcijski potencijal bude jednak onome na slobodnoj površini ili manji. Manji likvefakcijski potencijal ispod konstrukcije mogao bi se pokazati ako bi utjecaj njezine težine bio takav da vertikalna efektivna naprezanja ponište utjecaj statičkih posmičnih naprezanja, cikličkih naprezanja zbog odziva konstrukcije te dio cikličkih naprezanja koja bi se javila na slobodnoj površini.

\section{Zahvala}

Autori se zahvaljuju prof.dr.sc. Tomislavu Ivšiću sa Sveučilišta u Zagrebu na ustupanju vrlo dobro istraženih i detaljno opisanih profila tla u Osijeku ([14]). Također, autori se zahvaljuju recenzentima na njihovim sugestijama koje su unaprijedile kvalitetu rada.

\section{Literatura}

[1] Rollins, K.M.; Seed, H.B. 1990. Influence of buildings on potential liquefaction damage, Journal of Geotechnical Engineering, volumen 116, broj 2, str. 165-185

[2] Seed, H.B.; Idriss, I.M. 1982. Ground motions and soil liquefaction during earthquakes, Monograph Series, 5, Earthquake Engineering Research Institute, University of California, Berkeley, California

[3] Kramer S.L. 1996. Geotechnical earthquake engineering, Prentice Hall, Inc., Upper Saddle River, New Jersey

[4] Damage in Anchorage from an earthquake on March 27, 1964., U.S. Army photo. Dostupno na: http://www.universetoday.com/101404/the-sun-doesnt-cause-earthquakes/, pregledano 24.8.2013.

[5] Overturned buildings, Niigata 1964. Dostupno na: http://www.ce.washington.edu, pregledano 24.8.2013.

[6] Youd, T.L.; Idriss, I.M., 2001. Liquefaction resistance of soils: Summary report from the 1996 NCEER and 1998 NCEER/NSF workshops on evaluation of liquefaction resistance of soils, Journal of Geotechnical and Geoenvironmental Engineering, volumen 127, broj 4, str. 817-833 Dostupno na: http://www.ce.memphis.edu/7137/PDFs/Reference2/Youd\%20ad\%20ldriss.pdf, pregledano 2.12.2013.

[7] Boulanger, R.W.; Idriss, I.M. 2004. Evaluating the Potential for Liquefaction or Cyclic Failure of Silts and Clays, Report No. UCD/CGM-04/01, Center for Geotechnical Modeling, Department of Civil \& Environmental Engineering, College of Engineering, University of California at Davis. Dostupno na: 

19.8.2013.

[8] Boulanger, R.W.; Ziotopoulou, K. 2012. PM4Sand (Version 2): A Sand Plasticity Model for Earthquake Engineering Applications, Report No. UCD/CGM-12/01, Center for Geotechnical Modeling, Department of Civil \& Environmental Engineering, College of Engineering, University of California at Davis. Dostupno na: http://nees.ucdavis.edu/publications/Boulanger_Ziotopoulou_Sand_Model_CGM-12-01_2012.pdf, 19.8.2013.

[9] Bozorgnia, Y.; Bertero, V. 2004. Earthquake engineering from engineering seismology to performancebased design. CRC Press LLC

[10] Seed, H.B.; Idriss, I.M. 1971. Simplified procedure for evaluating soil liquefaction potential, Journal of Soil Mechanics and Foundations Division, volumen 97, broj 9, str. 1249-1273

[11] EN 1992-1:2004, Eurocode 2: Design of concrete structures - Part 1-1: General rules and rules for buildings, European Committe for Standardization, 2004

[12] Computers and Structures Inc. (CSI). 2009. SAP2000, structural analysis program. Version 14.1.0. Berkeley, California

[13] EN 1991-1:2004, Eurocode 1: Actions on structures - Part 1-1: General actions - Densities, self-weight, imposed loads for buildings, European Committe for Standardization, 2002

[14] Knjiga 13: geotehnički projekt, veljača 2008. Glavni projekt za izgradnju terminala za pretovar rasutih tereta u Luci Osijek, br. projekta 120-S-038, Sveučilište u Zagrebu, Građevinski Fakultet, Zavod za geotehniku

[15] Schnabel, P.B.; Lysmer, J.; Seed, H.B. 1972. SHAKE: A computer program for earthquake response analysis of horizontally layered sites. Report No. EERC 72-12, Earthquake Engineering Research Center, University of California, Berkeley, California

[16] EN 1998-1:2004, Eurocode 8: Design of structures for earthquake resistance - Part 1: General rules, seismic actions and rules for buildings, European Committe for Standardization, 2005

[17] Technical Report for the PEER Ground Motion Database Web Application, Beta Version - October 1, 2010. Dostupno na: http://peer.berkeley.edu/peer_ground_motion_database/Technical_Report.pdf, pregledano 24.8.2013.

[18] Stewart, J.P.; Stewart, A.F. 1997. Analysis of soil-structure interaction effects on building response from earthquake strong motion recordings at 58 site, Report No. UBC/EERC-97/01, Earthquake Engineering Research Centre, College of Engineering, University of California, Berkeley

[19] Stewart, J.P.; Seed, R.B.; Fenves, G.L. 1999. Seismic soil-structure interaction in buildings. II: Emprical findings, Journal of Geotechnical and Geoenvironmental Engineering, volumen 125, broj 1, str. 38-48

[20] Veletsos, A.S.; Wei, Y.T. 1971. Lateral and rocking vibrations of footings, Structural Research at Rice, Report No. 8, Department of Civil Engineering, Rice University, Houston, Texas

[21] Veletsos, A.S.; Verbič, B. 1973. Vibration of viscoelastic foundations, Journal of Earthquake Engineering \& Structural Dynamics, volumen 2, broj 1, str. 87-102

[22] Mylonakis, G.; Gazetas, G.; Nikolaou, S.; Chauncey, A., 2002. Development of analysis and design procedures for spread footings. Technical report MCEER-02-0003. Multidisciplinary center for Earthquake Engineering Research (MCEER), Bufallo, New York, USA. Dostupno na: https://mceer.buffalo.edu/publications/catalog/reports, pregledano 2.12.2013. 